\title{
Possibilities for Parent Participation: Including All Families in Their Children's Education
}

\author{
CATHERINE HANDS \\ Brock University
}

\begin{abstract}
Noting the critical role parent engagement plays in student achievement and wellbeing (see for example Epstein, 1995, 2001; Henderson, Mapp, Robinson, \& Davies, 2007), the paper looks at strengthening parent engagement, focusing on successful strategies for reaching, and supporting parents who face barriers to engagement such as poverty and cultural diversity issues. The paper focuses on five school board-level parent engagement projects qualitatively examined through observations, document analysis, and interviews with program coordinators, educators and parents. The boards conducted surveys and community visits to learn about families and their communities. Boards in regions with economic diversity covered the cost of activities involving parents, provided childcare or hosted family friendly events, and limited or eliminated transportation costs to events. Boards serving multicultural communities used translation services to communicate with families, hosted events in the communities, and developed culturally relevant activities. Findings point to the need for provincial education departments or ministries, universities and boards to work with educators to support inclusive initiatives that promote all families' participation in their children's education.
\end{abstract}

\section{Introduction}

Part of the problem is that schools assume they have nothing to get from the parents or community. I go in with the perspective that I have a lot to offer but also that I have a lot to gain. The biggest thing to be gained is not that parents come in and volunteer or help you with managing the child. When you partner with parents and they feel respected, a lot of times they become strong advocates for schools and communities. You cannot have a high performing school without strong parent advocates. For me that's the voice that's missing [in urban schools]. (Auerbach, 2011, p. 235)

This quotation from a principal at a mostly lower and middle class, culturally diverse school, encapsulates not only the lack of inclusion, but also the benefits of engaging families as partners in their children's education. Teachers, principals and school support staff are finding it more and more challenging to create the educational programs that meet the many different academic and social needs of the students in our economically and culturally diverse society 
(Davies, 2002; Henderson, Mapp, Robinson, \& Davies, 2007; Merz \& Furman, 1997). In response, some scholars have been recommending creating and nurturing partnerships between schools and families that are characterized by a shared focus on students, in order to assist all children to succeed academically, as well as to enhance their positive self-esteem, independence, and life skills (Darling-Hammond \& Lieberman, 1993; Davies, 2002; Epstein, 1995, 2001; Henderson et al., 2007; Hoover-Dempsey, Bassler, \& Brissie, 1992; Shapiro, Ginsberg, \& Brown, 2002). Research shows that opportunities for the co-construction of learning opportunities and school reform initiatives with input from all stakeholders, are most likely to contribute to enhancing student achievement, reducing achievement gaps and engaging families (Comer, Haynes, Joyner, \& Ben Avie, 1996; Jeynes, 2005; Pushor, 2007; Pushor \& Ruitenberg, 2005).

These ideas are gaining in popularity. A number of educators and their school boards in countries such as Canada and the United States of America are coming to the same conclusions that collaboration is a way to meet the students' needs and promote achievement (Hands, 2005). The membership of the National Network of Partnership Schools (NNPS), which is an organization that promotes school-family-community collaboration with a focus on students, supports this claim. Established in 1996 with 202 members (Hands, 2005), the NNPS has grown to 884 "active members committed to developing and maintaining strong programs of school, family and community partnerships linked to school improvement goals for student success" (NNPS, n.d.), including schools and districts, as well as state-level and community organizations.

Government education departments and funding foundations are following suit. In Ontario, for example, the Ministry of Education has established a Parent Engagement Office (PEO), which is dedicated to the development and support of parent engagement initiatives across the school districts in the province, through research and policy-making (see Ministry of Education, 2005). This is an important development in several ways. It demonstrates the recognized importance of parent engagement for student achievement and wellbeing, and it enables parent engagement practices across schools and boards in the province to be investigated and shared. At present, the Canadian literature and research base on parent engagement is limited (Pushor, 2007). It is valuable to examine parent engagement initiatives in a Canadian context, in order to develop policies and practices that reflect the environments of the children, families, schools and communities in Canada. 
This paper is based on Ontario Ministry of Education-funded research, which involved evaluating the benefits and challenges of eight Ministry-funded initiatives, in terms of their ability to strengthen parent engagement. For the purposes of this paper, I highlight the ways in which five initiatives in culturally or economically diverse communities engaged families that might otherwise not participate in their children's education. Initiatives such as literacy support for parents of grade one students in a French-language board, a rural board's resources for parents of children with mental health issues, and a board-wide speaker event to introduce parent engagement concepts to families and educators - while valuable, did not target cultural or economic challenges. In examining the five initiatives, I focus on: a) the ways in which each initiative contributes to parent engagement, and b) the successful strategies these projects used to reach and support parents who face barriers to engagement. In the section that follows, I outline a definition of parent engagement that is useful for the purposes of this study. I then describe factors that influence the breadth and depth of families' engagement in their children's education.

\section{Parent Engagement}

Described variously as parent or family involvement, engagement or participation, it is necessary to clarify what is meant by parent engagement. While parents can be broadly interpreted as any family members who have responsibility for the care and wellbeing of the children, including aunts, uncles and grandparents (Henderson, et al., 2007), there is less agreement about the terms describing their interaction with education. Some scholars make the distinction between parent involvement and parent engagement. For them, models of parent involvement place the focus on what parents can do to support goals and agendas for the school and the students established by educators in the schools and districts (Pushor, 2007). Here, decision-making is within the purview of school personnel, not the families. Parent engagement -or school-family partnership, on the other hand, involves families in determining educational agendas, as well as shared power and authority over education (Auerbach, 2011; Pushor, 2007), with an understanding that parents, too, possess knowledge that contributes to teaching and learning (Harvard Family Research Project, 2002; Pushor \& Ruitenberg, 2005).

It is this latter definition that frames parent engagement for the purposes of this paper. Increased parent engagement in their children's learning is the type of engagement that is most 
likely to enhance student achievement and reduce achievement gaps (Jeynes, 2005; Pushor, 2007). As a result, school or board initiatives that are supportive of parents engaged as meaningful partners in educational decision-making, and that provide all families with the tools to be engaged in their children's learning, are of particular interest. The broader expected goals here are to build confidence in the public education system and to promote the continuous improvement of the education system (Harvard Family Research Project, 2002).

\section{Issues of Inclusion}

All of these goals point to the importance of understanding the families and their community outside of the school in order to encourage parent engagement. When educators, researchers, and policymakers ask which parents are often not participants in school-family collaboration, they find that social and financial status, and cultural diversity are major influences. In examining the social and environmental factors that impact parent engagement, Leithwood and Jantzi's (2006) meta-analysis of 57 articles on parent engagement found that 22 studies reported "social class, language, race and/or economic status, were significant influences on the nature and quality of school-parent engagement" (p. 24). Families characterized as financially disadvantaged, as well as those from cultural minority groups may not be able to participate in their children's education in the same ways as other families.

Families that are from cultural minorities may be unable to participate if school interpretations of parent involvement are shaped by the dominant cultural practices (Auerbach, 2010; Olivos, 2006). Assisting small groups of children with reading and math in the classroom, putting together a class newsletter, or participating in fundraising, such as bake sales and raffles (Church \& Dollins, 2011), for example, may not be ways in which parents from cultural minorities are comfortable participating. Parents' perceptions of the education system can be negative, as a result. In their study of Latino parent participation, Quiocho and Daoud (2005) found that parents wanted to participate more but they felt excluded, and that some educators had misconceptions about the parents' roles and their ability to assist with their children's education. Cooper (2009) found that low-income, African-American mothers felt educators "devalued, dismissed and disrespected" them and their children. While these parents' perceptions do not mean that educators are actually disrespectful or racist (Olivos, 2011), they still made schoolfamily collaboration unlikely (Cooper, 2009). Moreover, it is increasingly important for 
educators to find ways of meeting families' diverse needs. Henderson, Mapp, Johnson, and Davies (2007) observe that achievement gaps are influenced in part by immigration. They note as the foreign-born population increases, "more children and families whose English is limited and who are not familiar with our school system or society" are being served by the schools (p. 5).

Families' financial circumstances might play a role in the amount and type of parent engagement at schools. For example, wealthy parents wield the power to shape and influence schools' curricula (Goldring, 1993; Oakes, Wells, Jones, \& Datnow, 1997). As well, upper middle-class families promote the reputations of schools due to their local influence in the community (Metz, 1986). On the other hand, parents without financial advantages typically do not have direct influence on their children's schooling (Metz, 1990), have little contact with educators, supporting their children's education at a distance from the school (Auerbach, 2011), and have difficulty participating at schools in the ways teachers would like (Lareau, 1987). For example, it may not be possible for parents who are financially disadvantaged to attend school events when they are scheduled, provide their children with educational resources to supplement their children's learning, or advocate for their children in ways more affluent families are able (Lareau, 1987, 2003).

Leithwood and Jantzi (2006) point out that these issues challenge educators in schools. For example, the reasons for parents not being more involved are not always evident, the personal and professional contexts experienced by families in financial poverty are often poorly understood by school personnel, and the expectations of some cultural groups for their children's education may not be consistent with the training, experience and expectations of the educators (Leithwood \& Jantzi, 2006). In response, some scholars point to the importance of communication in creating opportunities for families, teachers and principals to work together with a focus on student achievement and wellbeing (Quiocho \& Daoud, 2005; Hiatt-Michael, 2010). One might be tempted to assume the schools' teachers, principals and support staff are the ones to always provide the resources to families. Not so. They often have difficulty meeting all of their students' needs on their own (Henderson et al., 2007). This process works in a reciprocal way; the students and school personnel can provide family and community members with their resources, but families and community members can provide students and educators with resources, such as time, knowledge and skills, as well (Datnow, et al., 2002; Hands, 2005). 
Towards that end, Auerbach (2010) calls for the development of authentic partnerships: "respectful alliances among educators, families and community groups that value relationship building, dialogue across difference, and sharing power in pursuit of common purpose" (Auerbach, 2011, p. 5).

While explanations of the underlying causes of challenges to inclusion are useful in preparing inclusive parent engagement initiatives, an examination of initiatives that are actively seeking to include all families would be valuable. Given that everyone has knowledge and resources, and some families may have difficulty participating in their children's education, it's useful to look at parent engagement initiatives designed with a focus on inclusion and enhanced parent engagement.

\section{Strategy of Inquiry}

Noting the need for a deeper understanding of participants' experiences of the parent engagement initiatives, this investigation used a qualitative case study research design. In total, eight parent engagement initiatives with the goal to promote student achievement were involved in the research. While seven of the initiatives were district-led, one was parent-led across two districts. Data were collected regarding each of the initiatives. Semi-structured, open-ended interviews of approximately 45 minutes in length were conducted with initiative organizers and participants in the related activities, as well as others who may have noticed a difference in parent engagement as a result of the projects (e.g., teachers, principals), where possible. Twentyseven individual interviews and twenty focus group interviews were conducted, involving trustees (2), First Nations educational councilors and managers (4), community members (5), teachers (4), vice principals (4), supervisory officers (9), a director of education (1), a Ministry PEO representative (1), principals (16), board-level support staff and administrators (22), regional Parent Involvement Council and school council members (17), and parents (30). When possible, interviews took place during the events, and follow-up interviews were scheduled afterward. The interviews were digitally audio-recorded, and detailed field notes were taken during the interviews. Observations were made and field notes were taken during site visits. Documents and other artifacts from the initiatives, such as brochures, radio and printed advertisements, evaluation forms, and PEO final reports from the project coordinators were collected during and after site visits and from the PEO. Additionally, school board and Statistics 
Canada websites were accessed for contextual information. Demographic information was collected on the communities and the school districts, as well as information on the parent engagement initiatives, activities and resources for families. Multiple sources of data were sought in order to establish construct validity through triangulation (Merriam, 1998; Rothe, 2000).

Upon reviewing the audiorecordings and the interview notes, the archival data and the observations, the collected data were coded and analyzed for emerging categories and themes. The constant comparative method was utilized in which the data obtained from each participant were continuously examined and incidents were compared across the data (Bogdan \& Biklen, 1982; Merriam, 1998). In this way, new categories and themes were developed, and existing ones were evaluated and modified.

\section{Findings and Discussion}

In the section that follows, I focus on parent engagement strategies used in regions with cultural and/or economic diversity. Two annual parent conference events, a family literacy project, a district's board-developed parent engagement materials, an aboriginal family literacy initiative, and one board's multiple parent engagement initiatives all focused on cultural diversity and/or economic diversity (see Appendix A for a summary of each initiative). Several themes emerged during the data analysis that illustrated the initiatives' capacity for inclusivity. In the following subsections, I outline the strategies employed by the educators and program coordinators to enhance the accessibility of their initiatives.

\section{Who Are the Parents? Identifying the Families Being Served by the Schools and the Environment Beyond Their Walls}

In order to develop parent engagement programs in schools with a range of activities that meet the families' and schools' needs, it is necessary to gather information about the families and students (Epstein, 1995), as well as the broader communities, in order to find out how parents are currently involved in education. This involves consulting families directly when determining what they need, the types of parent engagement activities that would be appropriate (Henderson et al., 2007), and how families would like to contribute to their children's education. The educators and initiative coordinators used several different strategies to get this information. 


\section{Surveys of the parent community.}

Once the parent conferences were established, the board-based coordinating team in District A and the parent coordinators in Districts B and C distributed evaluation forms to the event attendees. The parents evaluated the usefulness of the conference sessions and workshops and made recommendations for future conference topics. Similarly, District I's team of coordinators for the Get Involved: Volunteer in Education (GIVE) program asked parents for feedback on the workshops, the topics covered, and recommendations for future program workshops. This kind of feedback was used to develop the next conference or program.

Two school boards in this study surveyed their parent community before developing parent engagement activities. District I developed a parent engagement audit as the first step in creating parent engagement programs at schools in the board. While not an inclusive list, it provided a variety of activities corresponding to Joyce Epstein's (1995) six types of parent involvement that could be developed. The audit could be used by teachers, principals and supervisory officers, for example, to identify and evaluate existing parent engagement activities, as well as pinpoint any activities that are needed. Also, two of three pilot schools for District G's initiative used a questionnaire to collect information on the parent community. Parent engagement was a recent focus for this school board. A working group of parents, community representatives, and school and district educators, developed a parent engagement handbook based on Epstein's (1995) types of involvement and a DVD for school councils to use to promote parent engagement, as well as on-line resources for all parents. The survey gave the school principals information regarding what parents needed and how they would like to be involved in education. In addition, they were able to identify the communication strategies that were best suited to the parent community.

As a District I supervisory officer with parent engagement in her portfolio, Roberta Mack stated,

I was at a [parent event] and one of the workers said to me, "Well, I don't know why they (the parents) didn't register.” And I'm thinking, “Well, why don't you know?” Ask.

Before you set stuff up, ask: "What works best for you?"

For all of these initiatives, the events were offered at times that were found to be convenient for many parents. The families were also able to effectively communicate the types of activities wanted or needed, to the educators. The use of surveys played an essential role in this, and made 
it possible to include as many parents as possible in their children's education (Epstein, 1995, 2001), through the initiatives.

\section{Surveys of the environment beyond the school or district.}

The school council training initiative in District I included guidance on collecting demographic information, district data on the population the schools served, surveying the school community, and auditing parent engagement practices to get a more complete picture of students', families' and schools' needs, and parent engagement.

Some surveys are done informally in person. Teacher home visits are an example of opportunities for one-to-one and face-to-face communication to create relationships, to find out what the teachers can do to assist families, to provide information on educational resources and opportunities for parent participation, and to promote parent engagement in education (ABC Head Start, n.d.; Hiatt-Michael, 2010). Before developing the speaker series to promote literacy and family engagement in education in District $\mathrm{H}$, the initiative coordinators visited the community served by the board. At those times, social services representatives, and school and central office personnel, gained an appreciation for the families' community and the environment in which their students were living. By encouraging aboriginal families' voice and agency as recommended by scholars (see Faircloth, 2011), they had a clearer idea of the families' strengths and the challenges they experienced. Also important, they gained an understanding of different ideas around family structures; extended family, as well as non-relatives were involved in caregiving, which was reflective of aboriginal communities (see Faircloth, 2011). The speaker series' coordinators were then better able to tailor the program to the families' needs.

With an understanding of the social context within the broader community as well as the characteristics of the families, it is possible to tailor parent engagement practices to suit the schools and families. Not having previous personal or professional experience with the students' and their families' life circumstances need not be the challenge that scholars like Leithwood and Jantzi (2006) found in the literature. Collecting data on the families and their surrounding community may be one way to turn a challenge into an opportunity for inclusive parent engagement. 


\section{Strategies to Reach and Support Parents Who Face Challenges to Engagement}

Most of the initiatives (Districts A, G, I, Parent-led conference in Districts B and C) were intended to meet the needs of all families. Their ultimate goal was to increase the numbers of parents engaged in their children's education. Several common challenges to parent engagement were identified across the districts, and the people who coordinated and participated in the initiatives used a variety of strategies to address those challenges.

\section{Poverty issues.}

Between $10 \%$ and $21 \%$ of the population that these districts served was identified as low income before taxes (Statistics Canada, 2006). Recognizing that the cost of events and programs for parents to attend might exclude some families, the initiatives were free of charge. For example, the conferences (District A, Parent-led conference), the GIVE program (District I), and the speaker events (District $\mathrm{H}$ ), did not cost the participating families any money. In some cases, the boards covered the costs. For some initiatives, some of the expense was defrayed through partnerships with local community organizations. For other initiatives, the organizers looked for contributors who would facilitate sessions in kind. One GIVE program coordinator observed, "It's a partnership, it works so well because none of us could do this alone. The only way this would work is to do this in partnership with our community partners." Another noted, "We were trying to beg, borrow and steal funding, or ask our community partners if they would deliver the training program." As a result, the local Parks and Recreation department, for example, provides some training for free through their programs as part of their mandate.

Another related issue is childcare. Families with small children may not be able to participate in event activities if they do not have access to childcare (Mackety \& LinderVanBerschot, as cited in Faircloth, 2011). This may be a particular concern for single-parent families. As Roberta observed, childcare needs to take into account families' schedules; with limited childcare availability, "you're appealing only to the people who have a flexible workday, and that's the professional class." "And increasingly, they don't, either," observed her colleague and collaborator on the New Teachers Induction Program handbook. Some initiatives were able to provide childcare during the events (Parent-led conference, one of District G's pilot schools). Other initiatives were family-friendly; that is, all members of the family were welcome and the activities appealed to family members of all ages (District G's pilot schools, District H). Yet 
another initiative (District I's GIVE program) was offered for half-days during school hours when fewer families would be affected by childcare needs. These strategies enabled more families to attend the events, with the potential to increase parent engagement.

Similarly, the cost of transportation needed to participate in the initiatives may be problematic for some families. Recognizing this, some initiatives attempted to minimize or eliminate this cost to the families. The GIVE program and the Parent-led conference were held in central locations in the regions and are accessible by public transit, for example. As one coordinator for the GIVE program stated, they work together with community partners... bringing schools ... to a central location ... so that families could get there on [public] transportation, easy access. [The programme is] not in the schools, we don't have room in the schools, this is number one. This is a school initiative to train people to work in schools, but we don't have any schools, or don't have any schools in the right place with the space to accommodate this training, so we have to partner [with community organizations].

District A's annual parent conference provided transportation to the event. Several bus stops across the city were established, and the parents could be picked up and dropped off at one of these stops by buses arranged for by the district. Other initiatives are delivered in the communities they serve. For example, the speaker events in District $H$ were held in each of the aboriginal communities the district serves. Other initiatives were implemented in the neighbourhood schools (Districts G and D), which may have limited or eliminated transportation costs and made the initiatives more accessible for families.

\section{Cultural issues.}

Several of the districts serve multicultural communities. Parents who are newcomers to the country and are unfamiliar with the Ontario education system, or who do not speak either of the official languages fluently, may not be able to participate in their children's education to the degree they might like (c.f. Auerbach, 2011; Leithwood \& Jantzi, 2006; Quiocho \& Daoud, 2005). As indicated in the research (see Quiocho \& Daoud, 2005; Leithwood \& Jantzi, 2006), translation services were found to be valuable in a large urban center with multicultural communities; however, they were needed in other districts with multicultural populations. While other districts (Districts A \& G, for example) had smaller populations of individuals representing 
diverse ethnicities, these families were not all being reached effectively. While efforts to translate school-home communication may be in place, translated information on the activities involving parents or during the activities in which the parents are participating, would likely make it easier for all families to be involved. For example, the organizers of the parent-led conference in Districts B and C, had advertising materials translated into the most commonly spoken languages or dialects in the city, and had government settlement workers at the event to translate the proceedings in the speaker sessions and workshops for families. Also, workshops on the Ontario education system were specifically included for parents who were newcomers, and DVDs in multiple languages were made available for attendees on participating in parent-teacher interviews. These were some of the ways that the conference coordinators enhanced the accessibility of this initiative and promote parents' engagement in their children's education. Similarly, Quiocho and Daoud (2005) found that translating school newsletters and bulletins, hiring a school-based community liaison to assist parents, and having staff members who speak parents' first languages, help to include all families.

Educators at other districts observed that some families' needs were not being met, and developed their parent engagement initiative to address the needs. As a result, certain types of families were targeted by the initiatives. District H's speaker events to promote literacy were aimed at families of aboriginal heritage. Aboriginal students' scores on Ontario's standardized tests were well below the provincial average. In the word of Tom Brant, the school board aboriginal education leader and event coordinator, school personnel

looked at the number of First Nations kids graduating at the [high school], and they could count them on one hand, and out of 200 graduates, there would be 5 First Nations people walking across the stage.... A lot of First Nations people haven't had positive experiences with education, whether they went to residential school or the way things were being done in school boards.

In the past, aboriginal community members have had little or no influence on the education planned and delivered; curricula and teaching strategies that were used "as a tool to acculturate and assimilate has resulted in a lingering distrust of the educational system for many Native peoples" (Faircloth, 2011, p. 126). Noting that it has been a challenge to engage aboriginal families in school activities, the sponsored events were held in the families' community, and they were culturally relevant with a message to families to promote literacy activities in the home. 
Likewise, noting the effectiveness of the practice in other communities, Quiocho and Daoud (2005) recommend holding meetings involving the parents not only in schools, but also in the community, in order to open up communication. As Tom observed, the speakers' event "is the first step in trying to do some things with the aboriginal communities... giving parents some optimism and some hope that things aren't how they were 20 years ago."

Some initiatives targeted both poverty and cultural issues. District I served many families in their culturally and economically diverse region. As a result, some parent engagement activities may have been particularly beneficial for newcomers to Canada and families characterized as low income. The GIVE program workshop series provided parent volunteers with training in child supervision, school board policy, effective communication, problemsolving and conflict resolution, for example. In addition to being free of charge to the participants, the GIVE program was co-sponsored by Ontario Works because it provides workrelated skills in a Canadian context. The Families and Schools Together (FAST) initiative was a commercial program designed to provide community resources and social support to low income, stressed and newcomer families, which was adopted by the board. Similarly, programs such as ABC Head Start in Edmonton, Alberta, connect families with health, education and community resources that help support their children from the time they enter school throughout their academic career (ABC Head Start, n.d.).

In all of the initiatives, therefore, the family unit is targeted, with an understanding that the initiatives enable families and educators to support their children together. As Roberta noted, parent engagement initiative coordinators need to

have a plan, but be open to suggestions..., have enough flexibility that you can allow it to go in the direction in which it needs to go, so you need to listen to what the respondents are saying to you, what the teachers say to you, what the principals say to you, what the parents say to you, what community partners are saying. So you need to be constantly checking, be checking, having checkpoints.

With an understanding of the challenges to participation, parent engagement initiative coordinators in this study created opportunities for all parents to engage in their children's education. 


\section{Conclusions and Implications}

In order to address high student achievement and reduce achievement gaps, it is essential to include all families in their children's education (Epstein, 2001; Henderson et al., 2007). Here, the features of the parent engagement initiatives in this study that hold promise for inclusive school-family relations, are highlighted through a discussion of the implications for policy, practice and research.

\section{Parents and Educators Develop Collaborative Activities}

Initiatives that are co-constructed by parents and school personnel have the potential to enhance parent engagement (Jeynes, 2005; Pushor, 2007). In this study, those initiatives that were co-constructed or developed by parents, or included capacity for parents to contribute to the development of initiatives through discussions, surveys and feedback forms, were reported to be successful and useful by the teachers, principals and responding families alike. When potential challenges were made known to the coordinators of the initiatives in this study, they took steps to address them, in order to facilitate the families' access to and engagement in the initiatives. The boards that were experiencing difficulty reaching all parents were in some cases unaware of the impact of the families' culture on parent engagement, for instance. This highlights the need to survey the community and parents when creating parent engagement opportunities. Moreover, this is a step toward developing the welcoming environment in schools that is necessary for parent engagement (Epstein, 2001; Faircloth, 2011; Henderson et al., 2007; Quiocho \& Daoud, 2005).

\section{Resources from Beyond the School Help to Enhance Inclusivity}

Once initiative coordinators have assessed the families' and school's needs, it may be that structures such as translation services, childcare, transportation, and free programming, are needed for all families to be able to participate in the parent engagement initiative, for example. These features come at an additional cost to the schools or the districts above and beyond the expense of the initiative. Also, some of the initiatives in this research were limited in scope by the availability of human and financial resources. For instance, the conferences are coordinated by volunteers on a part-time basis. The GIVE program does not have a full-time administrator to 
coordinate the program across the district or the funding to pay session facilitators so there are a limited number of programs running at any time.

Support from the provincial government to assist with the cost of providing services as well as administrative and production costs may help the schools and boards to create an inclusive program with a wider range to reach more families and community members where they might not otherwise be able to do so. It might also be possible for the Ministry of Education, for example, to provide guidance to districts interested in writing proposals for grants from community organizations to support their initiatives. This would benefit not only the schools, educators, families and students, but there is an opportunity for the boards and the Ministry of Education to build their reputations as well (see Hands, 2005; Lin, 1999). These initiatives and others like them may promote public education and enhance public opinion about the education provided, as they not only include families, but also representatives of community organizations. The district- and Ministry-sponsoring of events held in the community, as well as hosting events in schools, are valuable features of initiatives, as they make the education system transparent and school activities visible for all. This has the potential to foster public confidence in public education (Hanson, 2003).

\section{Building Parent Engagement Programs and Enhancing Existing Initiatives}

It is promising that a number of school boards support parent engagement. Having it as part of board-wide plans for school improvement, or having superintendents with parent engagement in their portfolios, provides support for parent engagement initiatives at the school level (Van Voorhis \& Sheldon, 2002). Since school personnel need to reach out to families and encourage parent engagement practices (Davies, 2002; Epstein, 1995), the future of these practices is also determined in part by the support for them among the educators in schools.

It is necessary to provide educational and professional development opportunities for preand in-service educators, to assist them in developing or enhancing parent engagement strategies (Dotger \& Bennett, 2010; Henderson \& Mapp, 2002) that meet their students' and programming needs, in an effort to enhance parent engagement. An examination of the types of programs and professional development opportunities currently available to train preservice and in-service teachers, and prospective administrators in principal preparation programs with regard to parent engagement, would be useful to identify the information about parent engagement that is 
available to educators. University teacher and principal education programs, the provincial government, professional organizations, school boards, and schools are all possible sources for the human, material and financial resources needed to develop professional learning opportunities around parent engagement.

Also, an examination of the strategies that are being used to measure the effects of parent engagement initiatives in these and other school boards would be valuable. Surveys of families and their feedback on initiatives is very useful; however, it would be helpful to know how the different parent engagement initiatives that are put into action affect parent engagement and ultimately, student achievement and wellbeing. This kind of evidence may prove to be useful when teachers, principals and supervisory officers are seeking funding from external organizations, school boards and/or government offices for the initiatives and resources needed.

This study brings together some informative ideas around parent engagement in the province. That said, further learning around parent engagement practices is needed in order to more widely establish parent engagement programs that include all families and have an impact on student achievement. Of note, this study was a qualitative examination of a small number of funded initiatives in Ontario, and the findings may not be generalizable to other schools or boards (see Merriam, 1998). Not only more qualitative research, but wide scale quantitative studies in Canada are required, in response to earlier calls for developing the national literature base (Pushor, 2007), and sharing best practices across schools and their boards. As we see, educators hold the key to inclusive parent engagement practices, by supporting families as active participants in their children's education, finding ways to include families in the co-construction of parent engagement initiatives, as well as identifying challenges to and strategies for the participation of all families. Only in this way are families able to be fully engaged as partners in their children's education.

\section{Notes}

This research was funded by the Ontario Ministry of Education's Parent Engagement Office.

Catherine Hands is currently appointed as an Assistant Professor at Brock University, where she teaches in the Administration and Leadership in Education program in the Faculty of Education. As a researcher, teacher and consultant, Catherine has worked with Ontario school boards, the Elementary Teachers' Federation of Ontario, and the Ontario Ministry of Education's Parent Engagement Office. Catherine's research interests stem from her experiences in the 
classroom, as well as her work with school leaders and teachers, and include school-community relations, family involvement in schooling, schools as communities, educational leadership, values and ethics in education, social justice, professional learning communities, and educational reform. She maintains an active research agenda in these areas, and has presented and published her work regionally, nationally and internationally.

\section{References}

ABC Head Start (n.d.). Program overview. Retrieved from $\mathrm{http}: / /$ abcheadstart.org/programOverview

Auerbach, S. (2010). Beyond coffee with the principal: Toward leadership for authentic schoolfamily partnerships. Journal of School Leadership, 20(6), 728-757.

Auerbach, S. (2011). Introduction: Why leadership for partnerships? In S. Auerbach (Ed.), School leadership for authentic family and community partnerships: Research perspectives for transforming practice (pp. 3-9). New York, NY: Routledge.

Bogdan, R. C., \& Biklen, S. K. (1982). Qualitative research for education: An introduction to theory and methods. Boston, MA: Allyn \& Bacon.

Church, K. L., \& Dollins, C. A. (2010). Parent engagement at school. In D. B. Hiatt-Michael (Ed.), Promising practices to support family involvement in schools (pp. 75-95). Charlotte, NC: Information Age.

Comer, J., Haynes, N., Joyner, E., \& Ben Avie, M. (1996). Rallying the whole village: The Comer process for reforming education. New York, NY: Teachers College Press.

Cooper, C. W. (2009). Parent involvement, African American mothers, and the politics of educational care. Equity \& Excellence in Education, 42(4), 379-394.

Datnow, A., Hubbard, L., \& Mehan, H. (2002). Extending educational reform: From one school to many. New York, NY: Routledge Falmer.

Davies, D. (2002). The $10^{\text {th }}$ school revisited: Are school/family/community partnerships on the reform agenda now? Phi Delta Kappan, 83(5), 388-392.

Dotger, B. H., \& Bennett, J. (2010). Educating teachers and school leaders for school-family partnerships. In D. B. Hiatt-Michael (Ed.), Promising practices to support family involvement in schools (pp. 129-149). Charlotte, NC: Information Age.

Dryfoos, J. (2002). Full-service community schools: Creating new institutions. Phi Delta Kappan, 83(5), 393-399.

Epstein, J. L. (1995). School/family/community partnerships: Caring for the children we share. Phi Delta Kappan, 76(9), 701-712.

Epstein, J. L. (2001). School, family, community partnerships: Preparing educators and improving schools. Boulder, CO: Westview Press.

Faircloth, S. (2011). Fostering inclusive educational environments for American Indian parents and families in urban schools and communities. In C. M. Hands \& L. Hubbard (Eds.), Including families and communities in urban education (pp. 119-138). Charlotte, NC: Information Age.

Goldring, E. B. (1993). Principals, parents, and administrative superiors. Educational Administration Quarterly, 29(1), 93-117.

Hands, C. M. (2005). Patterns of interdependency: The development of partnerships between schools and communities. (Unpublished doctoral dissertation). University of Toronto, Ontario, Canada. 
Hanson, K. J. (2003). Strong school-community partnerships: Opening the windows of public education. Leading \& Managing, 9(2), 153-159.

Harvard Family Research Project. (2002). Concepts and models of family involvement. Retrieved from http://www.gse.harvard.edu/hfrp/projects/fine/resources/case_study/intro.html\#top

Henderson, A. T., \& Mapp, K. L. (2002). A new wave of evidence: The impact of school, family, and community connections on student achievement. Austin, TX: Southwest Educational Development Laboratory.

Henderson, A. T., Mapp, K. L., Johnson, V. R., \& Davies, D. (2007). Beyond the bake sale: The essential guide to family-school partnerships. New York, NY: The New Press.

Hiatt-Michael, D. B. (2010). Communication practices that bridge home with school. In D. B. Hiatt-Michael (Ed.), Promising practices to support family involvement in schools (pp. 25-55). Charlotte, NC: Information Age.

Hoover-Dempsey, K. V., Bassler, O. C., \& Brissie, J. S. (1992). Exploration in parent-school relations. Journal of Educational Research, 85, 287-294.

Jeynes, W. H. (2005). A Meta-analysis of the relation of parental involvement to urban elementary school student academic achievement. Urban Education, 40(3), 237-269.

Lareau, A. (1987). Social class differences in family-school relationships: The importance of cultural capital. Sociology of Education, 60, 73-85.

Lareau, A. (2003). Unequal childhoods: Class, race and family life. Berkeley, CA: University of California Press.

Leithwood, K., \& Jantzi, D. (2006, January). A critical review of the parent engagement literature: Final report. Toronto, ON: Ontario Ministry of Education.

Lin, N. (1999). Building a network theory of social capital. Connections, 22(1), 28-51.

Merriam, S. B. (1998). Qualitative research and case study applications in education. San Francisco, CA: Jossey-Bass.

Merz, C., \& Furman, G. (1997). Community and schools: Promise and paradox. New York, NY: Teachers College Press.

Metz, M. H. (1986). Different by design: The context and character of three magnet schools. London: Routledge and Kegan Paul.

Metz, M. H. (1990). How social class differences shape teachers' work. In M. W. McLaughlin, J. E. Talbert, \& N. Bascia (Eds.), The contexts of teaching in secondary schools (pp. 40107). New York, NY: Teachers College Press.

Ministry of Education. (2005, December). Developing partners in education. Retrieved from http://www.edu.gov.on.ca/eng/document/nr/05.12/developing.pdf

National Network of Partnership Schools (n.d.). Our growing network member tally. Retrieved from http://www.csos.jhu.edu/p2000/map.htm

Oakes, J., Wells, A. S., Jones, M., \& Datnow, A. (1997). Detracking: The social construction of ability, cultural politics, and resistance to reform. Teachers College Record, 98(3), 482510.

Olivos, E. M. (2006). The power of parents: A critical perspective of bicultural parent involvement in public schools. New York, NY: Peter Lang.

Olivos, E. M. (2011). Authentic engagement with bicultural parents and communities: The role of school leaders. In S. Auerbach (Ed.), School leadership for authentic family and community partnerships: Research perspectives for transforming practice (pp. 3-9). New York, NY: Routledge. 
Quiocho, A. M. L., \& Daoud, A. M. (2005). Dispelling myths about Latino parent participation in schools. The Educational Forum, 70, 255-267.

Pushor, D. (2007, January). Parent engagement: Creating a shared world. Paper presented at the Ontario Education Research Symposium, Toronto, Ontario, Canada.

Pushor, D., Ruitenberg, C., with co-researchers from Princess Alexandra Community School. (2005, November). Parent engagement and leadership: Research report, project \#134. Saskatoon, SK: Dr. Stirling McDowell Foundation for Research into Teaching.

Rothe, J. P. (2000). Undertaking qualitative research. Edmonton, AB: The University of Alberta Press.

Statistics Canada. (2006). 2006 community profiles. Retrieved from http://www12.statcan.ca/census-recensement/2006/dp-pd/prof/92-591/index.cfm?Lang=E

Van Voorhis, F. L., \& Sheldon, S. B. (2002, April). Five-year study: Developing quality partnership programs in schools. Paper presented at the annual meeting of the American Educational Research Association, New Orleans, LA.

Yin, R. K. (1994). Case study research: Design and methods (2nd ed.). Thousand Oaks, CA: Sage Publications.

Appendix A

Parent Engagement Initiative Descriptions 


\begin{tabular}{|c|c|c|}
\hline $\begin{array}{c}\text { Parent } \\
\text { Engagement } \\
\text { Initiative } \\
\end{array}$ & Community & Description \\
\hline $\begin{array}{l}\text { Board-led } \\
\text { parent } \\
\text { conference in } \\
\text { Catholic } \\
\text { District A }\end{array}$ & $\begin{array}{l}\text { mid-sized urban } \\
\text { centre } \\
\text { culturally diverse: } \\
\text { approximately } 24 \% \\
\text { of the population } \\
\text { identifies as } \\
\text { immigrant, } \\
\text { approximately } 11 \% \\
\text { speak a language } \\
\text { other than English or } \\
\text { French at home } \\
\text { economically } \\
\text { diverse: } 50 \% \text { of all } \\
\text { families earn more } \\
\text { than provincial } \\
\text { average, } 16 \% \\
\text { classified as low } \\
\text { income before taxes }\end{array}$ & 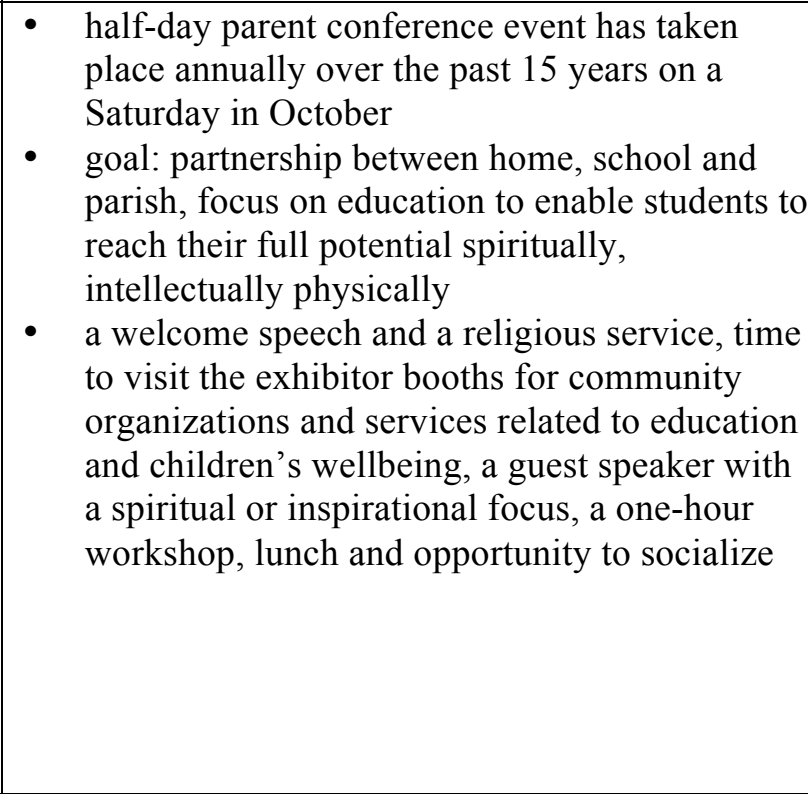 \\
\hline $\begin{array}{l}\text { Parent-led } \\
\text { conference in } \\
\text { District B \& } \\
\text { Catholic } \\
\text { District C }\end{array}$ & 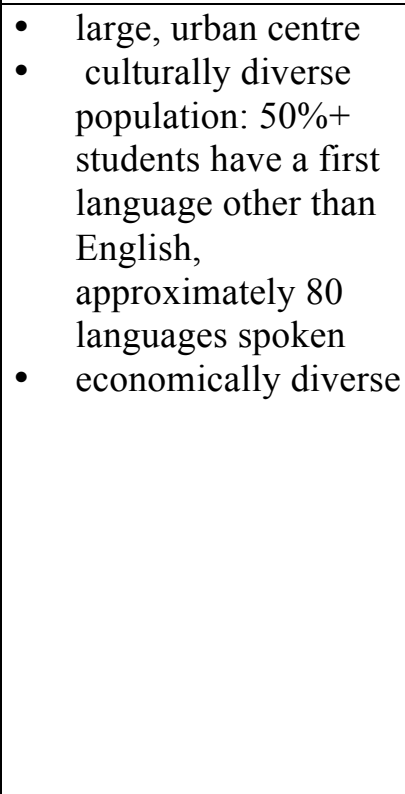 & $\begin{array}{l}\text { - } \quad \text { annual one-day conference held on a Saturday } \\
\text { trustees reach out to parents across the various } \\
\text { cultural groups being served and encourage an } \\
\text { understanding and appreciation of their role in } \\
\text { the educational success of their children, with } \\
\text { the goal of improved student success in the } \\
\text { schools } \\
\text { morning speakers and a keynote address, } \\
\text { attendees participate in one of eight 1.5-hour } \\
\text { workshops, lunch break with entertainment } \\
\text { provided by students from the two districts, } \\
\text { choice of another of the eight workshop topics } \\
\text { in the afternoon } \\
\text { time to visit the community organizations' and } \\
\text { services' exhibitor booths and to socialize with } \\
\text { one another in the morning and during the } \\
\text { afternoon break }\end{array}$ \\
\hline $\begin{array}{l}\text { Program } \\
\text { implementation } \\
\text { and materials } \\
\text { developed for } \\
\text { parent } \\
\text { engagement in } \\
\text { Catholic } \\
\text { District G }\end{array}$ & $\begin{array}{l}\text { mid-sized urban } \\
\text { centre } \\
\text { some cultural } \\
\text { diversity } \\
\text { low to middle } \\
\text { income range: } 50 \% \\
\text { of all families earn } \\
\text { less than the } \\
\text { provincial average, } \\
\text { approximately } 13 \% \\
\text { classified low }\end{array}$ & $\begin{array}{l}\text { On-line resources, a DVD for parents and a } \\
\text { parent engagement handbook used by school } \\
\text { council members to support and encourage } \\
\text { parents to be involved with their children's } \\
\text { learning at a school and system level } \\
\text { goal: enhancing parent engagement in the } \\
\text { classroom, school and system levels with a } \\
\text { focus on student achievement and character } \\
\text { education } \\
\text { - The handbook explains the types of } \\
\text { involvement and how parent activities can be }\end{array}$ \\
\hline
\end{tabular}




\begin{tabular}{|c|c|c|}
\hline & income before taxes & $\begin{array}{l}\text { applied to the district's school foci of literacy, } \\
\text { numeracy, school climate, and Catholic } \\
\text { identity, and how to get parents involved in } \\
\text { education } \\
\text { on-line version of the handbook is available for } \\
\text { downloading, as well as documents e.g., parent } \\
\text { checklists for establishing positive relationships } \\
\text { with school personnel and improving } \\
\text { communications with teachers, and parent } \\
\text { engagement survey templates that can be } \\
\text { adapted for use at individual schools } \\
\text { a DVD on parent involvement is available to } \\
\text { the parents and school personnel, and is shown } \\
\text { at schools during school-wide events }\end{array}$ \\
\hline $\begin{array}{l}\text { Literacy } \\
\text { workshops for } \\
\text { aboriginal } \\
\text { families and } \\
\text { principals in } \\
\text { District H }\end{array}$ & $\begin{array}{ll}- & \text { mainly rural } \\
\text { region in } \\
\text { northern Ontario } \\
\text { approximately } \\
17 \% \text { of the } \\
\text { population self- } \\
\text { identify as being } \\
\text { of aboriginal } \\
\text { heritage }\end{array}$ & 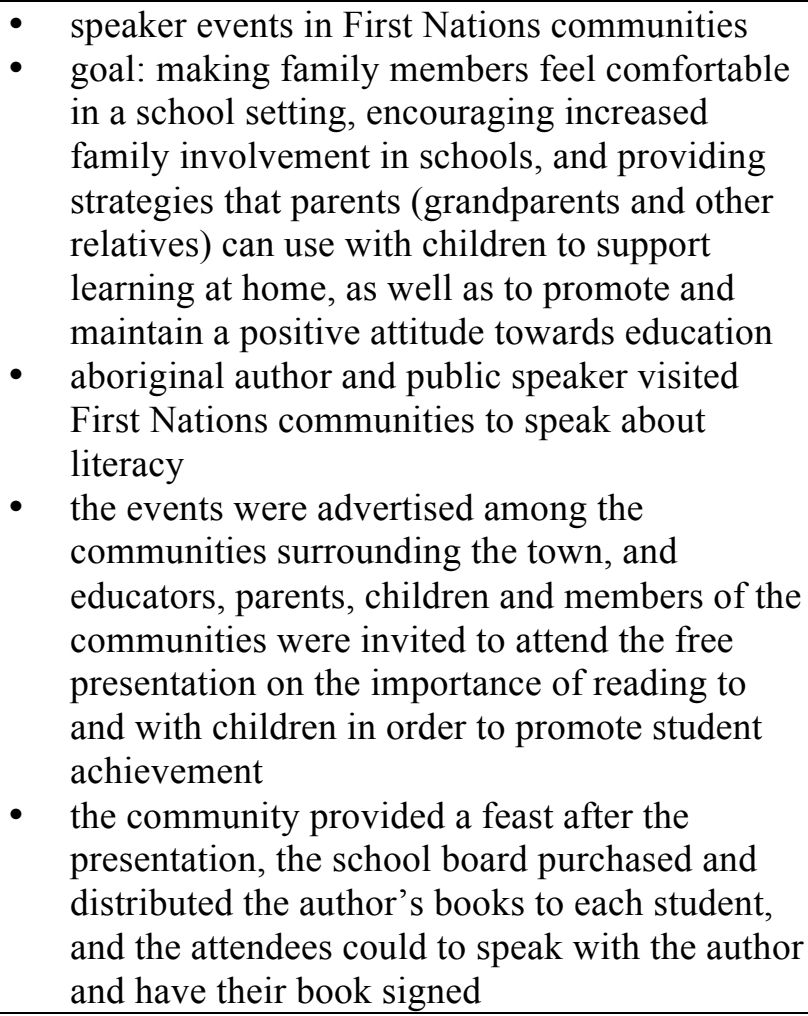 \\
\hline $\begin{array}{l}\text { Comprehensive } \\
\text { parent } \\
\text { engagement } \\
\text { strategy in } \\
\text { District I }\end{array}$ & $\begin{array}{l}\text { mid-sized urban } \\
\text { centre, and rural } \\
\text { regions } \\
\text { economically and } \\
\text { culturally diverse: } \\
\text { primarily low } \\
\text { income in the } \\
\text { northern quadrant, } \\
\text { culturally diverse in } \\
\text { the western, central } \\
\text { and eastern } \\
\text { quadrants (up to } 90 \\
\text { languages spoken by } \\
\text { students and their }\end{array}$ & 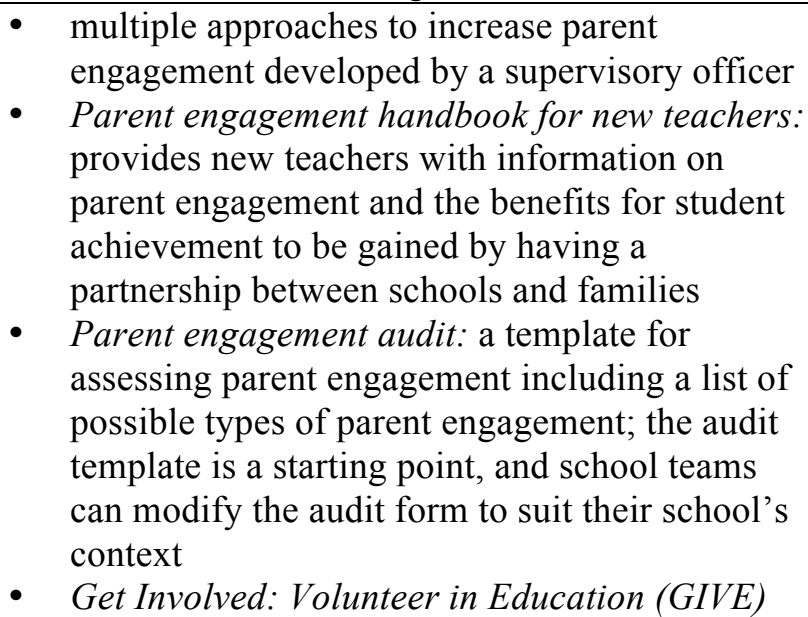 \\
\hline
\end{tabular}




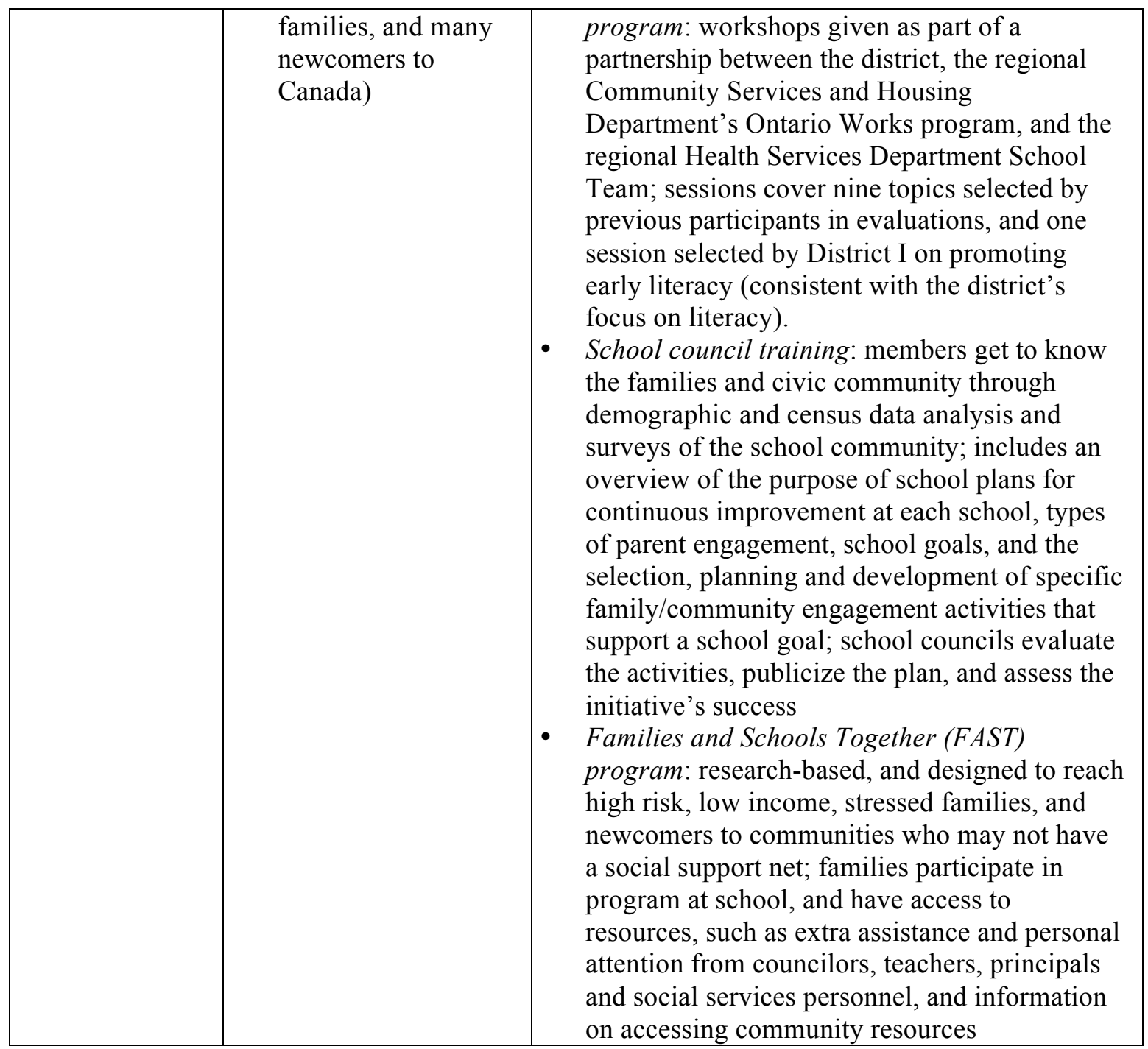

